\title{
Review of profile and prenatal care for women with gestational diabetes mellitus
}

\author{
Avaliação do perfil e dos cuidados no pré-natal de mulheres com diabetes mellitus \\ gestacional
}

\section{Revisión de perfil y el cuidado prenatal para las mujeres con diabetes mellitus gestacional}

Francisca Adriele Vieira Neta ${ }^{1}$, Vicente Lima Crisóstomo ${ }^{2}$, Régia Christina Moura Barbosa Castro ${ }^{2}$,Sarah Maria Fraxe Pessoa ${ }^{1}$, Maria Marly Santos Aragão $^{1}$, Cinthia Gondim Pereira Calou ${ }^{3}$

The study aimed to identify the sociodemographic, clinical and obstetric profile, as well as prenatal care of women with gestational diabetes mellitus. This is a cross-sectional study with 50 women in a public maternity in Fortaleza in the period from November 2012 to September 2013. It was observed an average age of 31.34 years, early prenatal care in the first trimester $(76.0 \%)$ abdominal birth in $(63.6 \%)$ and non-drug treatment $(78.0 \%)$. The associated pathologies were hypertension (18.0\%), premature rupture of membranes (16.0\%) and placental abruption (16\%). In $18.0 \%$ the glycemia was not evaluated by the professional as well as checking blood pressure in $2.0 \%$; $(8.0 \%)$ had no assessment of auscultation of the fetus heartbeat and the uterine height was not evidenced (4.0\%). These findings emphasize the need for interventions to ensure pregnant women with diabetes mellitus an adequate assistance, preventing complications to the mother and child. Descriptors: Diabetes, Gestational; Pregnancy, High-Risk; Obstetric Nursing.

Objetivou identificar o perfil sociodemográfico, clínico-obstétrico, bem como os cuidados no pré-natal de mulheres com diabetes mellitus gestacional. Estudo transversal realizado com 50 mulheres, em uma maternidade pública de Fortaleza, CE, Brasil, de novembro de 2012 a setembro de 2013. Constatou-se uma idade média de 31,34 anos, início do pré-natal no primeiro trimestre (76,0\%), parto abdominal em 63,6\% e tratamento não medicamentoso em 78,0\%. As patologias associadas foram hipertensão (18,0\%), amniorrexe prematura $(16,0 \%)$ e descolamento prematuro da placenta $(16,0 \%)$. Em 18,0\% a glicemia não foi avaliada na admissão hospitalar, assim como a verificação da pressão arterial (2,0\%), 8,0\% não tiveram a avaliação da ausculta dos batimentos cardíacos do feto e 4,0\% a altura uterina. Esses achados apontam para necessidade de intervenções que assegurem a gestante com diabetes mellitus uma assistência adequada, prevenindo complicações ao binômio mãe e filho.

Descritores: Diabetes Gestacional; Gravidez de Alto Risco; Enfermagem Obstétrica.

El objetivo fue identificar el perfil sociodemográfico, clínico y obstétrico, así como la atención prenatal de mujeres con diabetes mellitus gestacional. Estudio transversal, con 50 mujeres, en una maternidad pública de Fortaleza, CE, Brasil, de noviembre 2012 a septiembre 2013. Se constató edad promedia de 31,34 años, atención prenatal temprana en el primer trimestre (76,0\%), parto abdominal $(63,6 \%)$ y tratamiento no farmacológico $(78,0 \%)$. Las patologías asociadas fueron hipertensión arterial (18,0\%), ruptura prematura de membranas (16,0\%) y desprendimiento precoz de la placenta (16,0\%). En 18.0\%, la glucosa no fue evaluada en la admisión hospitalaria, así como la comprobación de la presión arterial 2,0\%; 8,0\% no tenían la evaluación de la auscultación de los batimientos del corazón del feto y 4,0\% de la altura uterina. Estos resultados señalan la necesidad de intervenciones que garanticen a la embarazada con diabetes mellitus asistencia adecuada, previniendo complicaciones al binomio madre e hijo.

Descriptores: Diabetes Gestacional; Embarazo de Alto Riesgo; Enfermería Obstétrica.

\footnotetext{
${ }^{1}$ Maternidade Escola Assis Chateuabriand. Fortaleza, CE, Brazil.

${ }^{2}$ Universidade Federal do Ceará. Fortaleza, CE, Brazil.

${ }^{3}$ Universidade Regional do Cariri. Crato, CE, Brazil.
} 


\section{Introduction}

The term gestational diabetes mellitus has been used to define any level of carbohydrate intolerance, resulting in hyperglycemia of variable severity with beginning or diagnosed during pregnancy. The appearance of this pathology can be explained by the elevation of counterregulatory hormones of insulin at physiological stress imposed by pregnancy and predetermining factors (genetic or environmental). The main hormone associated with insulin resistance during pregnancy is the placental lactogenic hormone, however, it is known that other hyperglycemic hormones such as cortisol, estrogen, progesterone and prolactin are also involved ${ }^{(1-2)}$.

Approximately $7 \%$ of pregnancies are associated with maternal and foetal complications, resulting in more than 200,000 cases per year of gestational diabetes mellitus registered in the National Health System, representing a major cause of maternal mortality in the country ${ }^{(3)}$.

Thus, the prior recognition of risk factors for gestational diabetes mellitus during prenatal becomes important to prevent complications. Thus, patients older than 25 years; overweight or obese people; with first-degree family history of diabetes and/or hypertension; users of hyperglycemic drugs; women with polycystic ovary and/or metabolic syndrome; with a history of recurrent pregnancy loss; polyhydramnios; macrosomia and stillbirth deserve special care and special attention in prenatal ${ }^{(4)}$.

In Brazil, the Ministry of Health recommends tracking the disease at the first visit for all pregnant women, using the fasting glucose and the risk factors as parameters. The tracking will be positive when the fasting glucose is $\geq 85 \mathrm{mg} / \mathrm{dl}$ and/or in the presence of a risk factor. In these conditions it is imposed the need for diagnostic testing with $75 \mathrm{~g}$ of glucose, from 24 weeks during the catabolic phase of pregnancy ${ }^{(5)}$. Every pregnant woman and her escort should be counselled about the risks of the disease and benefits of tracking for diabetes.
The new parameters of the glucose tolerance test with $75 \mathrm{~g}$ for the diagnosis of gestational diabetes mellitus are $92 \mathrm{mg} / \mathrm{dl}$ for fasting glucose; $180 \mathrm{mg} / \mathrm{dl}$ for glucose in 1 hour and $153 \mathrm{mg} / \mathrm{dl}$ glucose in two hours after oral overload ${ }^{(5-6)}$. Thus, the diagnosis of gestational diabetes mellitus will be confirmed for only an equal or greater amount than the predefined limits. After diagnosis, these mothers should be included in the treatment protocol for prevention of adverse maternal and perinatal outcomes.

From this perspective, prenatal care should prioritize health education and important care, such as diet, physical activity, glycemic control and guidance to drug treatment in order to prevent an adverse outcome for mother and newborn.

For the foregoing, we observe the importance of early diagnosis of this pathology because of complications such as metabolic decompensation, which can progress to ketoacidosis, the recurring urinary infections with the risk of acute pyelonephritis, the simultaneous appearance of hypertension disease, risk to abortion, premature delivery, dystocia and birth defects ${ }^{(2)}$.

Aiming to contribute to the assistance to this group of pregnant women, it was proposed to develop this study, whose purpose is to identify the sociodemographic, clinical and obstetric profile and care in prenatal women diagnosed with gestational diabetes mellitus.

\section{Method}

It is a cross-sectional exploratory study with a quantitative approach, performed in a public maternity integrated into the Health System in the city of Fortaleza, Ceará. That maternity is composed of 124 obstetric beds, $40 \%$ of those allocated to highrisk pregnancy.

All patients (pregnant and postpartum women) hospitalized for control of gestational diabetes mellitus in the period from November 2012 to September 2013 in obstetric clinic were included 
in the study. The inclusion criteria for the study were medical confirmation of diabetes mellitus during pregnancy, be 18 years old or older and have attached to the record the prenatal card. A sample of 50 patients was totalized, with a loss of five women who did not meet the inclusion criteria.

Data collection occurred between the first and fifth day of patient admission, by consultation of the medical record, prenatal card and a face to face interview.

Age, marital status, race, occupation, period of pregnancy and childbirth cycle, type of delivery of the current pregnancy, fasting plasma glucose value of the interview day, type of treatment given and pathologies were the variables extracted from patients' records.

As for the data of prenatal card, the beginning of the quarter prenatal, professional who held the consultations and some care (blood pressure measurement, assessment of uterine height and foetal heart rate) were obtained. We emphasize that the indicators of care were evaluated from the second trimester of pregnancy, considering enough time to check the quality during consultations.

The interview took place in a private room in a hospital unit with the purpose of complementing the data collected from medical records and prenatal card. Questions directed to the women's participation in health education activities during pregnancy, type of occupation, educational level, household income, and gestational age who was diagnosed with gestational diabetes mellitus were asked.

After collection, the data were organized into a database in Microsoft Excel for Windows (2007 version) program and calculated the absolute and percentage frequency.

The research considered the ethical principles of confidentiality, secrecy and anonymity recommended by Resolution 466/2012, the National Health Council. Its beginning occurred after the approval of the study proposal by the Ethics Committee with the Opinion 013/12. To implement the data collection, the participants were instructed about the purpose of the research and its free decision to participate or not, being able to withdraw at any time. After a detailed explanation of the study, participants were invited to signing the informed consent authorizing the research.

\section{Results}

The gestational diabetes mellitus occurred predominantly in tanned women; aged 28-37 years (average 31.34 years; standard deviation \pm 6.3; minimum age of 18 and maximum of 46 years). Among them $(11 ; 22.0 \%)$ became pregnant over 37 years. Most of them had partner (43; 86.0\%), were employed (43; 86.0\%), with high school education (33; 66.0\%). More than half of the women received an equal or below the minimum wage $(26 ; 52.0 \%)$ (Table 1).

Table 1 - Women distribution according to sociodemographics variables

\begin{tabular}{lc}
\hline Variales & n (\%) \\
\hline Age (years) & $14(28.0)$ \\
$18-27$ & $25(50.0)$ \\
$28-37$ & $11(22.0)$ \\
$>37$ & \\
Marital status & $43(86.0)$ \\
With partner & $7(14.0)$ \\
Without partner & \\
Ethnicity (self-reported) & $18(36.0)$ \\
White & $26(52.0)$ \\
Parda & $6(12.0)$ \\
Negra & \\
Occupational status & $7(14.0)$ \\
Unemployed & $43(86.0)$ \\
Employed & \\
Educacional level & $12(24.0)$ \\
Elementary school & $33(66.0)$ \\
High school & $5(10.0)$ \\
Higher level & \\
Monthly family income (minimum wage) & $26(52.0)$ \\
$\leq 1$ & $24(48.0)$ \\
\hline *2 minimum wage at the time the study was R\$622.00 in 2012 and $\mathrm{R} \$ 678.00$ in 2013
\end{tabular}


From women with gestational diabetes, 28 (56.0\%) were pregnant and the others $(22 ; 44.0 \%)$ in the postpartum period, whose birth was surgical (14; 63.6\%). Of these women, a significant portion (76.0\%) began prenatal care in the first trimester of pregnancy.

The diagnosis was established after the 20th week of pregnancy $(39 ; 78.0 \%)$. Between the first and fourth day of admission, the data from glycemic control presented $(37 ; 74.0 \%)$ normoglycemic and 13 (26.0\%) with abnormal glucose levels. Among the participants, 39 (78.0\%) controlled blood glucose with diet and / or physical activity (Table 2).

Table 2 - Distribution of women according to clinical and obstetric variables, glucose level and treatment for gestational diabetes mellitus

\begin{tabular}{|c|c|}
\hline Variables & n (\%) \\
\hline \multicolumn{2}{|c|}{ Period of pregnancy and childbirth cycle } \\
\hline Pregnant & $28(56.0)$ \\
\hline Puerperal & $22(44.0)$ \\
\hline \multicolumn{2}{|c|}{ Type of delivery (current pregnancy) $n=22$} \\
\hline Surgical & $14(63.6)$ \\
\hline Vaginal & $8(36.4)$ \\
\hline \multicolumn{2}{|c|}{ Early prenatal care (quarter) } \\
\hline First & $38(76.0)$ \\
\hline Second & $11(22.0)$ \\
\hline Third & $1(2.0)$ \\
\hline \multicolumn{2}{|c|}{ Professional who performed the prenatal } \\
\hline Nurse & $2(4.0)$ \\
\hline Doctor & $29(58.0)$ \\
\hline Doctor + Nurse & $19(38.0)$ \\
\hline \multicolumn{2}{|c|}{$\begin{array}{l}\text { Gestational age and diagnosis of gestational } \\
\text { diabetes mellitus (weeks) }\end{array}$} \\
\hline$\leq 20$ & $10(20.0)$ \\
\hline$>20$ & $39(78.0)$ \\
\hline Puerperium & $1(2.0)$ \\
\hline \multicolumn{2}{|l|}{ Hyperglycemia } \\
\hline Yes & $13(26.0)$ \\
\hline No & $37(74.0)$ \\
\hline \multicolumn{2}{|c|}{ Treatment for gestational diabetes mellitus } \\
\hline Nonpharmacological & $39(78.0)$ \\
\hline Oral hypoglycemic & $4(8.0)$ \\
\hline Insulin & $7(14.0)$ \\
\hline
\end{tabular}

The association of gestational diabetes mellitus with other pathologies (Table 3) were present in $76.0 \%$ of pregnant women, being the systemic hypertension the most prevalent (18.0\%), followed by premature rupture of membranes $(16.0 \%)$ and premature detachment of the placenta in $16.0 \%$ of participants. This finding reveals the magnitude of gestational diabetes mellitus, which reinforces the importance of research on these and other diseases through specific tests during prenatal.

Table 3 - Pathologies during pregnancy among women with gestational diabetes mellitus

\begin{tabular}{lc}
\hline Variables & $\mathbf{n}(\mathbf{\%})$ \\
\hline None & $12(24.0)$ \\
Hypertension & $9(18.0)$ \\
Amniorrhexis & $8(16.0)$ \\
Placenta previa & $8(16.0)$ \\
Anemia & $5(10.0)$ \\
Urinary infection & $4(8.0)$ \\
Asthma & $2(4.0)$ \\
Hypothyroidism & $1(2.0)$ \\
Obesity & $1(2.0)$ \\
Total & $50(100.0)$ \\
\hline
\end{tabular}

Some health care needed during prenatal care were evaluated after the first trimester, showing deficiency in the frequency of execution. $18.0 \%$ of women blood glucose was not evaluated; $2.0 \%$ did not have the blood pressure measuredt; $4.0 \%$ had no assessment of uterine height and $8.0 \%$ foetal heartbeats were not evaluated (Table 4). Aiming to strengthen care for complications prevention arised from the disease, health education activities such as lectures and groups of women were questioned. Only $40.0 \%$ of the interviewed women participated in some health education activity. Concerning the activities mentioned, all reported having participated in lectures and / or received some information during consultations about diet, physical activity and insulin use. None took part of the pregnant group. 
Table 4 - Pre-natal care

\begin{tabular}{lc}
\hline Variables & $\mathbf{n}(\%)$ \\
\hline Verification of capillary blood glucose & $41(82.0)$ \\
Yes & $9(18.0)$ \\
No & \\
Blood pressure check (number of times) & $1(2.0)$ \\
None & $2(4.0)$ \\
1 a 3 & $16(32.0)$ \\
4 a 6 & $31(62.0)$ \\
$>6$ & \\
Assessment of uterine height & $48(96.0)$ \\
Yes & $2(4.0)$ \\
No & \\
Evaluation of foetal heart rate & $46(92.0)$ \\
Yes & $4(8.0)$ \\
No & \\
Participation in educational activities & $20(40.0)$ \\
Yes & $30(60.0)$ \\
No & $50(100.0)$ \\
Total &
\end{tabular}

\section{Discussion}

Pregnancy and childbirth at the extremes of reproductive age have always been considered biohazardous for woman. Pregnancy over the age 35 is configured in an increasingly common reality observed nowadays, being related to changes in lifestyle; in which women postpone pregnancy over professional and personal goals. In this context, the gestational diabetes mellitus is characterized as a disease associated with advanced maternal age condition, but researchers warn that age cannot be analyzed in isolation, other important factors, such as obesity and family history may be present in younger women $^{(7-8)}$.

The relationship of race and gestational diabetes mellitus needs more detailed investigations, considering that many studies, including the Brazilian study of gestational diabetes mellitus found no association, this fact can be explained by the great miscegenation found in Brazil(7).

In this study women with better education had a higher incidence of gestational diabetes mellitus. A cohort study conducted in Pelotas in 4243 postpartum women at risk for developing the disease, confirms it (7). The analysis of the study raised the possibility that women with higher level of education perceive the signs and symptoms of the disease early, recognizing the risk factors for gestational diabetes mellitus and seek diagnosis and treatment in an adequate time. This finding appears as positive for $\mathrm{n}$ women's health promotion, considering the access to information and care necessary for a healthy pregnancy.

In the context of gestational diabetes mellitus having a good family income is important for the treatment adherence, emphasizing the acquisition of strips for home blood glucose control, access to dietary foods and transportation for consultation. However, recent studies indicate unfavourable combination of formal work with glycemic decompensation ${ }^{(7-8)}$. This factcan be explained by the lack of attention, at the same time, with respect to good eating habits depending on workload, triggering the. These factors contribute to habits like smoking, alcohol consumption, eating fast food and sedentary lifestyle that maintains a direct relationship with diabetes mellitus.

An integrative review on the relationship between pre-pregnancy eating habits and the onset of diabetes mellitus was developed, it was found that overweight was variable presented in a majority of women diagnosed with the disease, being related to the consumption of an inadequate diet with low fruit and vegetables, prevailing feeding fast food ${ }^{(9)}$.

Weight gain during pregnancy increases the risk of foetal macrosomia, being these, factors that predispose to operative delivery ${ }^{(2)}$. This study demonstrated a significant frequency of cesarean delivery. Similar results were identified in pregnant women with gestational diabetes mellitus in Ribeirão Preto-SP and previous studies conducted in the maternity ward of current research ${ }^{(8-11)}$.

However, gestational diabetes is not an indication for cesarean section, and the mode of delivery is an obstetric decision, the evaluation of the permeability of the maternal pelvis and its proportion to the size is required foetal. In deliveries 
with prolonged evolution, careful re-evaluation of foetal-pelvic proportions must be made in order to avoid dystocia. If signs of imbalance were identified, caesarean section should be indicated. Overall, the preference for caesarean occurs when the cervix is not conducive to induction, the foetus is macrosomic, presence of foetal distress and risk of intrauterine death as a result of poor control of glucose $\mathrm{e}^{(2-8)}$.

The World Health Organization considers the early initiation of prenatal care as essential for appropriate assistance, as well as the optimal number of queries, emphasizing a quantitative equal or greater than to six, ensuring monitoring of woman and baby health, as well as guidance on childbirth, postpartum, care of the newborn and breastfeeding promotion ${ }^{(12)}$.

In prenatal care of women with gestational diabetes mellitus, are essential the frequency of visits, maternal metabolic control and the assessment of foetal well-being. As a recommendation, consultations must be fortnightly, the diagnosis of gestational diabetes mellitus until the 32th week and thereafter weekly until delivery ${ }^{(2-8)}$.

Among the professionals who performed prenatal in the present study, the doctor led the queries, followed by interconsultation between doctors and nurses. Only a minority of consultations was held by the nurse alone. This fact can be justified for being the medical professional who performs prenatal high-risk, but that fact does not absolve the role of multidisciplinary team, including nurses.

With respect to prenatal care, the nurse must be able to identify factors or conditions related to risks and problems to woman health and foetus, in particular, gestational diabetes mellitus. Thus, early identification of women with gestational risk is essential so that appropriate interventions as investigation the disease predisposing factors, proper monitoring and referrals can be instituted immediately, increasing the probability of changing the outcome and provide a positive outcome ${ }^{(13)}$.

However, it is essential to reflect on the reasons why a significant portion of the early participants had not sought the health service, being exposed the metabolic changes and the risks posed by the disease. The quality of prenatal care is related to quality of professional that meets and Health System. For early monitoring and prevention of complications, especially maternal mortality, active surveillance of high-risk pregnancies and comprehensive care is needed as well as referral to specialist services in a adequate time.

Among the care during pregnancy in women with diabetes, self-monitoring blood glucose provides useful information for daily diabetes management. It is considered as ideal blood glucose levels during pregnancy: fasting <95mg/dl; 1 hour postprandial $<140 \mathrm{mg} / \mathrm{dl}$ and 2 hours postprandial $<\mathrm{h} 120 \mathrm{mg} / \mathrm{dl}$, adopted by the American Diabetes Association ${ }^{(4)}$.

However, these tests are not able to provide the mother and the health care team a quantitative and reliable measure of blood glucose over a prolonged period. So the ideal is to associate the capillary blood glucose with a measurement of glycated hemoglobin. The latter proved to be able to predict the risk of developing many complications for mother and foetus $^{(2)}$.

Values over $6.5 \%$ of glycated hemoglobin are directly associated with foetal loss. A study with diabetic pregnant women at a maternity hospital in Portugal, showed significant occurrence of foetal loss before 24 weeks gestation whose women had elevated levels of glycated hemoglobin ${ }^{(14)}$.

Several studies have found an association between hyperglycemia and maternal and foetal risks, and increase the value of glycemic is the most important determinant for complications. The most prevalent pregnancy/foetal complications are congenital malformations, miscarriage and macrosomia $^{(2,8,14-15)}$.

Concerning the prevention of complications during pregnancy, it is found the importance of glycemic control with diet, physical activity and drug treatment. Nutritional counselling is the first choice of treatment for gestational diabetes ${ }^{(15)}$. The American 
Diabetes Association recommends to limit the intake of carbohydrates to $40 \%$ of total calories associated with the prescription of diet with low glycemic index ${ }^{(2)}$.

Physical activity in gestational diabetes mellitus aims to decrease glucose intolerance, through cardiovascular fitness and intra-abdominal fat, to increase blood flow in insulin-sensitive tissues and reduction of free fatty acids ${ }^{(2-7)}$. The rupture of membranes, preterm labour, hypertensive disorders in pregnancy, restricted foetal growth, bleeding, multiple gestation and decompensated diabetes are contraindications to physical exercise ${ }^{(2)}$.

As for drug therapy, insulin is introduced when diet and exercise do not lead to adequate glycemic control (15). Although they have long been forbidden during pregnancy, some oral hypoglycemic agents such as metformin are being used as therapeutic choice. Metformin has similar efficacy and safety to insulin in perinatal and neonatal outcomes and maternal glycemic control ${ }^{(16)}$.

There is increased risk of maternal complications associated with gestational diabetes, highlighting the worsening of pre-hypertension, urinary tract infection, pre-eclampsia and obstetric complications $^{(8,15)}$.

For some authors, in studies with diabetic pregnant women, the tendency to high blood pressure and consequently pre-eclampsia occurs mainly in obese and insulin-resistant women ${ }^{(2-8)}$.

Regarding the onset of urinary tract infection, this presents as a common clinical problem among women with diabetes mellitus. Such women have a higher frequency of symptomatic infections compared to those without diabetes. Urinary infections in this same group are usually more severe, with high frequency of bacteremia and bilateral renal involvement, increasing the risk of hospitalization for pyelonephritis $^{(17)}$.

Moreover, pregnancy is a situation that predisposes to urinary tract infections due to physiological changes (hormonal and mechanical) that occur during this period of a woman's life.

The care established in prenatal women with diabetes aim to reduce the incidence of maternal and foetal complications, approaching the incidence in the general population, through adequate metabolic control, monitoring the foetal surveillance and the associated conditions for pregnant women ${ }^{(2)}$.

The assessment of prenatal care in this study revealed a deficiency of quality provided. There were a significant number of pregnant women without glucose monitoring, with unsatisfactory checking of blood pressure, lack of assessment of uterine height and foetal heart rate.

The glucose monitoring is an essential care to improve the obstetric prognosis of diabetes pregnancies, since hyperglycemia is considered the most important determinant of obstetrical risks ${ }^{(2-14)}$.

In the clinical evaluation of these women, it is also essential to check blood pressure, as it is the worsening of pre-existing hypertension and preeclampsia, complications of larger associations with gestational diabetes mellitus ${ }^{(15-18)}$.

Facing the complications of the newborn, stands out the foetal macrosomia and prematurity. Evaluation of uterine height and foetal heart rate were essential care to all pregnant women during prenatal care, resulting in the prevention of morbidity for both. As noted, there were a representative number of women who did not receive such care.

It is common the lack of qualified professionals to carry out health education during pregnancy, as well as the lack of planning of these services aiming the appreciation of the pregnancy as a phenomenon to be experienced in a particular way by the pregnant ${ }^{(19)}$.

The condition of high risk pregnancies requires guidance from professionals with diverse approaches to change behaviour related to lifestyle. Approaches require strategies such as health education for better understanding about the pathology of diabetic pregnant women, increasing the level of confidence and motivation for self-care ${ }^{(5-13)}$. 


\section{Conclusion}

The data show patients with diabetes mellitus without adequate monitoring to prevent complications exposing the serious risks both mother and newborn, revealing the need for implementation of existing health policies for early detection and appropriate management of the disease, before and after gestation.

It was found that a significant number of the participants showed any pathology associated with gestational diabetes mellitus during pregnancy, being hypertension, premature rupture of membranes and premature separation of the placenta more frequent. These complications should be highlighted in the prenatal query through effective and qualitative professional approach.

The results revealed unsatisfactory care during the prenatal, as the absence of a blood pressure check, uterine height and lack of glycemic value, reinforcing the unpreparedness of professionals to work with pregnant women with gestational diabetes mellitus.

The nursing care is important in assisting women throughout the puerperal cycle, helping to minimize risks to the mother and newborn, as well as the future life of the woman.

Thus, we expected to have contributed to the understanding of the profile and prenatal care for women diagnosed with gestational diabetes mellitus, highlighting the need for studies with larger sample size to define more precisely the sociodemographic, clinical, and obstetric findings and variables that compose the care during pregnancy and childbirth of this group.

\section{Colaboration}

Vieira Neta FA, Crisóstomo VL and Castro RCMB contributed to the conception, analyse, data interpretation, article composition and approval of the final version to be published. Pessoa SMF, Aragão MMS and Calou CGP contributed to the article composition.

\section{References}

1. Freitas P, Matos CV, Kimura AF. Profile of mothers of newborns with blood glucose control in the first hours of life. Rev Esc Enferm USP. 2010; 44(3):636-41.

2. Freitas F, Costa-Martins SH, Ramos JGL, Magalhães JA. Rotina em obstetrícia. Porto Alegre: Artmed; 2011.

3. Bolognanil CV, Souza SS, Calderon IMP. Diabetes mellitus gestacional - enfoque nos novos critérios diagnósticos. Rev Com Ciênc Saúde. 2011; 22(Sup 1):31-42.

4. American Diabetes Association. Diagnosis and classification of diabetes mellitus. Diabetes Care, 2011; 34(Suppl. 1):62-9.

5. Ministério da Saúde (BR). Secretaria de Atenção à Saúde. Departamento de Ações Programáticas e Estratégicas. Gestação de alto risco: manual técnico. Brasília: Ministério da Saúde; 2010.

6. International Association of Diabetes and Pregnancy study Groups Consensus Panel. International association of diabetes and pregnancy study groups recommendations on the diagnosis and classification of hyperglycemia in pregnancy. Diabetes Care. 2010; 33(3):676-82.

7. Dode MASO, Santos IS. Fatores de riscos para diabetes mellitus gestacional na coorte de nascimentos de Pelotas, Rio Grande do Sul, Brasil, 2004. Cad Saúde Pública. 2009; 25(5):1141-52.

8. Oliveira MIV, Bezerra MGA, Bezerra Filho JG, Veras MAC, Bezerra JP. Perfil de mães e recém-nascidos na presença do diabetes mellitus gestacional. Rev Rene. 2009; 10(4):28-36.

9. Instituto Brasileiro de Geografia e Estatística (IBGE). Pesquisa nacional por amostra de domicílios: síntese de indicadores 2012. Rio de Janeiro: IBGE; 2013.

10. Barbosa VLP, Reis LBSM. Acompanhamento nutricional na prevenção de complicações perinatais em gestantes com diabetes mellitus. Com Ciênc Saúde. 2012; 23(1):73-80.

11. Texeira CRS, Franco LJ, Monteiro RA, Granado F. Diabetes nos partos hospitalares em sistemas de saúde público e privado. Rev Saúde Pública. 2013; 47(3):460-9. 
12. Ministério da Saúde (BR). Secretaria de Atenção à Saúde. Departamento de Atenção Básica. Atenção ao pré-natal de baixo risco. Brasília: Ministério da Saúde; 2013.

13. Luciano MP, Silva EF, Cechetto FH. Orientações de enfermagem na gestação de alto risco: percepções e perfil de gestantes. Rev Enferm UFPE on line. [periódico na Internet] 2011 [citado 2014 jun 20]; 5(5):1261-6. Disponível em: http://www.revista. ufpe.br/revistaenfermagem/index.php/revista/ article/view/1727/pdf_559

14. Fernandes RSR, Simões AFB, Figueiredo ACN, Ribeiro ARS, Aleixo FMF, Aragüés SMDTG, et al. Prognóstico obstétrico de pacientes portadores de diabetes mellitus pré-gestacional. Rev Bras Ginecol Obstet. 2012; 34(11):494-8.

15. Nogueira AI, Santos JSS, Santos LLB, Salomon IMM, Abrantes MM, Aguiar RALP. Diabetes Gestacional: perfil e evolução de um grupo de pacientes do Hospital das Clínicas da UFMG. Rev Med Minas Gerais. 2011; 21(1):32-41.
16. Weinert LS, Silveiro SP, Oppermann ML, Salazar CC, Simionato BM, Siebeneichler A, et al. Diabetes gestacional: um algoritmo de tratamento multidisciplinar. Arq Bras Endocrinol Metab. 2011; 55(7):435-45.

17. Baumgartena MCDS, Silva VGDS, Mastalirb FP, Klausb F, Azevedo PA. Infecção Urinária na gestação: uma revisão da literatura. Cient Ciênc Biol Saúde. 2011;13(Esp):333-42.

18. Hayes C. Long-term prognostic factors in the diagnosis of gestational diabetes. Br J Nurs. 2009; 18(9):523-4.

19. Souza VB, Roecker S, Marcon SS. Ações educativas durante a assistência pré-natal: percepção de gestantes atendidas na rede básica de MaringáPR. Rev Eletr Enf. [periódico na Internet] 2011 [citado 2014 jun 20]; 13(2):199-210. Disponível em: http://www.revistas.ufg.br/index.php/fen/ article/view/10162/9621 